than on temperature. In this connection in 1940 he had been invited by the Air Ministry to give advice on a research on the icing of aircraft and he thought by now these results must be available.

In connection with sea ice, the Reverend W. L. S. FLeming said that before the war he had hoped that more detailed information could have been obtained from the whaling companies about the distribution of icebergs and sea ice in the Southern Ocean. With the resumption of whaling it should now be possible to obtain this information. It would be necessary to adopt a satisfactory method of recording it.

Dr. B. ROBERTS stated that the Danes had formulated standard methods of reporting and mapping sea ice; he hoped that it would be possible for the Society to keep in close touch with them with a view to reaching international agreement about the general use of the improved methods of reporting developed during the war.

Cdr. Burgess added that the Admiralty had ice charts for all the Arctic and the extreme North Atlantic showing the average limit over the last twenty or thirty years, and also the extreme limit. Danish reports as well as Russian and captured German atlases had been used during the war.

Lt.-Cdr. Glen stated that a system of reporting had been improvised during the first sortie in March 1942, by which the type of ice was recorded by letter indices and its quantity in tenths of sea covered. This was later modified and worked satisfactorily, except that examination of the photographs revealed that the observers exaggerated the amount of sea covered by about threetenths.

Dr. RoBERTs said that the Polar Research Institute, when trying to work out a satisfactory method of reporting sea ice, had made use of vertical air photographs taken of the pack ice off East Greenland. The estimates made by experienced polar voyagers in one photograph varied between five- and eight-tenths of sea covered by ice, when the amount by actual measurements was seven-tenths. These estimates from photographs showed much greater variations than when meteorologists used a similar scale for estimating cloud cover.

Lt.-Cdr. GLen added that it was only at the beginning that there had been a tendency to overestimate the amount of ice and to underestimate the amount of water, especially when the ice had been much broken up. With increased experience the observations became much more accurate.

With reference to the ice lanes, Lt.-Cdr. E. B. RHEAD said that these only appeared after gales and lay in the direction of the wind. He always expected to find them if there was a strong wind blowing off the ice.

At the conclusion of the meeting Dr. Odell proposed a vote of thanks to the speakers and those who had contributed to the discussion, which was seconded by Mr. Seligman, who also thanked Cdr. Burgess for attending the meeting and for giving much assistance in its preparation.

\title{
GENERAL MEETING
}

held at the Geographical School, Cambridge, on Friday, 26 April 1946 at 8 p.m.

13 members and 39 visitors were present

ThE President said that the Minute book containing the Minutes of the last General Meeting (22 October 1945) would be left available for inspection and in the absence of comment would be signed at the end of the meeting.

I. President's Report. The President said that the membership of the Society had reached 100 and that he hoped shortly to enrol several new Canadian members.

The Snow Survey of the British Isles would be recommenced next winter. The cooperation of Dr. E. L. Hawke and other members of the Royal Meteorological Society had been secured for this work. 
2. Future Papers. The next General Meeting would be held on July 18 , at which the Reverend W. L. S. Fleming would read a paper on the glaciological results of the United States Antarctic Service Expedition of 1939-4I. The Committee had that day decided that there should be one more meeting this year, to take place about the beginning of November. No decision had been reached regarding the paper to be read, but if in the meanwhile there were any suggestions these would be welcomed.

3. The President informed members that the International Commission of Snow and Glaciers would meet in Oslo during 1947. (Further particulars will be found on p. 35 of this issue.)

4. The President then asked Mr. J. M. Wordie to take the Chair. Mr. Wordie called upon Mr. G. Seligman to read his paper. Mr. Seligman then read the paper which, together with the discussion, is reported below.

\section{EXTRUSION FLOW IN GLACIERS}

$A$ description of tests to prove the hypothesis and some details regarding its influence on glacial erosion

\section{By G. Seligman}

IN the middle of last century, Agassiz, Tyndall and others showed that a glacier flowed faster at its centre than at its margin. Partly from experiments and partly from the assumption that it behaved like a river, it became generally accepted that it also flowed faster at the surface than lower down. This belief was held until ten or fifteen years ago although search through earlier literature shows that evidence was accumulating which might disprove this.

During the thirties of this century several writers began actively to re-examine the question. ${ }^{1}$ In 1937 the late Dr. M. Demorest, ${ }^{2}$ reporting on a West Greenland glacier, wrote that owing to plastic flow the ice was, as it were, forced out from under an ice cap at places where accumulation of snow lay deepest. He cited well-known laboratory experiments showing that ice tended to flow when under differential pressure.

In the following year, Dr. R. Streiff-Becker published his first paper ${ }^{3}$ asserting that in many parts of a glacier, flow was faster below than above.

Demorest used the evidence of glacial striae in old glacier beds. On the other hand Streiff-Becker developed his hypothesis by certain measurements and this paper has been written from material submitted by him.

He had been measuring snow accumulation on the Claridenfirn (Canton Glarus) yearly since 1916 and it occurred to him that if the accumulated firn was not to raise the level of the glacier, it must be carried away faster than appeared from the rate of flow measured at the surface. His measurements of the glacier level showed that the firn moved in waves but that the mean level of the surface was no higher in 1937 than it had been in 1916. Fig. I, p.r3, shows the position of a post, Point 2900 , through which is drawn a line EDC recorded in the

1 See for instance Hollingworth, S. E. Q.F. Geol. Soc. Vol. 87, 1931, p. 345 .

${ }^{2}$ Demorest, M. Zt. Gletscherk. Vol. 24, 1937, p. 45.

${ }^{3}$ Streiff-Becker. R. Zt. Gletscherk. Vol. 25, 1938, p. I. 